\title{
Clarification of Rules of Acceptance in Making Business Contracts
}

\author{
Dr. Md. Abdul Jalil \\ Associate Professor of Law \\ Department of Business Administration, Faculty of Economics and Management \\ International Islamic University Malaysia (IIUM) \\ E-mail: abduljali1@iiu.edu.my, abd_jalil2@yahoo.com
}

\begin{abstract}
Business firms and Business corporations enter into thousands of contracts everyday. Making a formal and written contract is very important for business corporations and firms although oral contracts are accepted and recognized by law. There are certain rules on making a valid formal contract. If the business firms do not have knowledge of those contract formation rules and they make contracts in ignorance of those rules, their contracts would be liable to be declared as null and void by the court of law if it is referred to it to determine its validity or to get a remedy for breach of contracts by one of the parties in the contract. In this paper I have not discussed all the elements of a valid contract. I have discussed only one of the fundamental elements of a valid contract that is 'acceptance'. In a business contract, there must have be an 'offer' and an 'acceptance', to make a valid contract, if not the contract will not be valid, recognized and enforceable in the court of law. The objective of this paper is to clarify the rules of making a valid 'acceptance' which may lead to making a binding contract between the parties.
\end{abstract}

Keywords: Offer, Acceptance, Rules of acceptance, Communication of acceptance, Unqualified acceptance, Revocation of acceptance

\section{Introduction}

'Acceptance' is one of the fundamental elements for making a binding contract. It is essential to determine when an acceptance is complete and a binding contract emerges. At the beginning of a business contract, the parties negotiate among themselves to buy certain goods or real property. When this negotiation takws a long time, it becomes difficult to determine when an effective acceptance has taken place (Mulcahy and Tillotson, 2004; Ball, 1983).

To accept an offer, it must come to the knowledge of the offeree. In other words, the offeror must communicate the offer to the offeree. If the offer is communicated by letter through the post office but does not reach the offeree, the offer does not come to the knowledge of the offeror. Therefore, the offeree cannot accept it as he has no knowledge about the offer. How he (offeree) can accept the offer which has not brought to his knowledge (Hudson, 1968). Hence, to accept an offer it must be communicated to the offeree. To communicate the offer, the offeror may utilize any one of different communication media available at present time. It is not essential that the offeror himself has to communicate the offer to the offeree; an authorized person on behalf of the offeror may effectively communicate the offer to the offeree and in that case the offeree can accept the offer and the acceptance will be valid and binding.

To make a valid contract acceptance is pertinent. Similarly, the acceptance must be communicated to the offeror. An acceptance is effectively communicated to the offeree when it comes to the knowledge of the offeree. If it does not come to the knowledge of the offeree, as a general rule, the acceptance would not be valid (Pheng and Detta, 2009; Coote, 1974). After sending the acceptance, if the offeree thinks that he has made a mistake and he wants to revoke the acceptance, he is allowed to do that under law but he needs to follow a specific rule. The rule is that he can only effectively revoke the acceptance before it comes to the knowledge of the offeror. If the acceptance has already reached the knowledge of the offeror, the offeree cannot revoke the acceptance. In that case the revocation would not be effective and enforceable against the offeror.

Under postal rule, it is not necessary to bring the acceptance to the knowledge of the offeror. An acceptance is duly completed under postal rule at the moment when the offeree posts the acceptance letter (properly addressed), no matter whether the offeror receives the acceptance letter or not. It may happen that the letter goes missing on the way through the post office and the offeror does not receive it or he receives it but after a long time has passed. Nevertheless, in such situations, the acceptance is complete and binding on the offeror although it has not come to his knowledge.

Regarding revocation of acceptance by post, the rule is different from formation of a contract. The postal rule provides that to revoke an acceptance, just posting the revocation letter in the post office is not enough. The revocation letter must be received by the offeror to be an effective revocation of the acceptance and this revocation must be before the receipt of the acceptance letter by the offeror and not afterwards (Hudson, 1966). 
Acceptance can be communicated expressly for example, by face-to-face communication or by telephone or by writing a letter sent through the post office. Nevertheless, acceptance can be implied by conduct. For example, almost daily we buy goods from shopping centers or shops. We do not formally or expressly pronounce the words 'offer' and 'acceptance'. Selling and buying take place by conduct of parties without having to formally communicate the acceptance to the seller. Therefore, it is not always necessary to communicate the acceptance formally, by conduct of the parties the court can presume intention of the parties and can determine an effective acceptance.

Silence cannot constitute an acceptance on the part of the offeror. For example, the offeree says: 'I want to buy your Proton Perdana car for RM50,000 and if you are silent on this proposal, I will presume that you have accepted my offer.' If the seller is silent, can the offeree say that there has been an effective acceptance by the silence of the offeror and a binding contract has emerged? The answer is no, the law clearly states that silence cannot constitute an effective acceptance. The acceptance must be express and clear (O'Sullivan and Hilliard, 2006; Mulcahy and Tillotson, 2004).

From the brief discussion above, I find that a few questions arise out of the law of acceptance. They are: i) What is acceptance? ii) What are the prerequisites of a valid acceptance? iii) In what ways and in what manner can an acceptance be made? iv) Does silence constitute an effective acceptance? v) What are the rules for the communication of an acceptance? vi) Can the communication of acceptance be waived and if so in what circumstances? vii) Can the acceptance be revoked? If yes, when and how? These questions along with some other important issues related to the acceptance of an offer to make a valid contract are discussed and analyzed in this paper by applying descriptive and analytical research methodology. The paper analyzed data from books, journals, case reports, legislation and opinions of legal scholars etc. The paper only discusses relevant laws from Malaysian and the UK. Other countries laws have not been discussed and compared.

\section{Definition and Nature of Acceptance}

Section 2(b) of the Contract Act 1950 (Malaysia) provides that when the person to whom the proposal is made signifies his assent thereto, the proposal is said to have been accepted. A proposal, when accepted, becomes a promise. The person who accepts the proposal is called the promisee (Section 2(c) of the Contract Act 1950 Malaysia).

Section 9 of the Contract Act 1950 (Malaysia) provides that so far as the acceptance of any promise is made in words, the acceptance is said to be expressed. If the acceptance is made other than in words, the acceptance is said to be implied. Whether the acceptance is express or implied, the main point is that it must be absolute (final) and unqualified in order to be effective.

So, to be an acceptance, the offeree must agree to the terms of the offer unqualified. According to O'Sullivan and Hilliard (2006): "An acceptance is a clear indication of the offeree's unqualified agreement to the terms of the offer in the manner set out in the offer."

Final and unqualified assent to the terms of the offer is known as acceptance and it is made in the manner specified or indicated by the offeror (Jalil et al, 2002). The offeree must accept the terms of the offer as they are, without any modification. If he modifies the terms of the offer, there is no acceptance, rather the offeree makes a counter-offer (Majid and Arjunan, 2007). An example will make it clear. Let's say, Mr. X has offered to sell his shop for US\$1000 to Y. Y says, 'I am very interested in buying the shop but I can only pay US\$950. Here, Y has not accepted the offer unqualified. He has modified the terms of the offer and the modification has initiated a counter-offer by Y. So, there has been no acceptance.

There are different types of acceptance, usually of three types: i. acceptance by conduct; ii. oral acceptance; and iii. Acceptance in writing. When we go to a supermarket to buy some goods, we take the necessary items from the shelf and put them in the basket. Later we take the items to the cashier to pay the price of the goods taken. Placing the goods in front of the cashier for payment amounts to making an offer to buy the goods and if the cashier takes the items, scans price tag on the items and we accept the price for the goods, then we accept the offer. Here, the cashier in the supermarket accepts the offer by conduct (Furmston, 2001).

Acceptance can be oral and oral acceptance is valid. An example of oral acceptance is like this: I tell a person who is well-versed in SPSS program, "If you teach me SPSS two hours a week, I will pay you US $\$ 40$." The person starts teaching me SPSS every week for two hours. Here, the person has accepted my offer orally. It is an oral acceptance and I am bound to pay him US $\$ 40$ for each week.

Similarly, acceptance can be in writing. Contract law does not specifically state that a contract must be in writing. So, an oral contract is also valid. However, it is better to have a written contract than an oral contract to prove the 
terms of the offer and acceptance so that no party in the contract can deny the truth of the agreed terms as they are written and signed by the parties. So, when an acceptance is made in writing, it is known as written acceptance. For example, the offeror may state in this offer that, "HP laptop for sale for US\$1000 each. The acceptance must be submitted in writing by Friday before 5:00 pm at my office." If a customer accepts the offer and submits the acceptance in writing to the offeror's office, a written acceptance is made and the offeror is bound by the written acceptance.

\section{Requisites of a Valid Acceptance}

Section 7(a) of the Contract Act 1950 provides that in order for a proposal to be converted into a promise, the acceptance of that proposal must be absolute and unqualified. Absolute and unqualified acceptance means the terms of the offer has not been modified or changed by the offeree. If the offeree bargains on the offer and modifies the terms of the offer, let's say he asks the seller (offeror) to reduce the price of the goods which has been proposed to sell, then there will be no acceptance. Because the buyer has modified the price (by asking the seller to reduce the price) and thereby he has not accepted the offer, rather he has made a new offer to buy the goods with reduced price which in fact rejects the original offer.

As stated earlier, acceptance must be absolute and unqualified so that there is complete consensus between the offeror and the offeree. If the parties are still negotiating, an agreement has not yet formed. In Lau Bother \& Co. v. Chin Pacific Navigation Co. Ltd (1965), negotiations for the delivery of logs were conducted through a series of telegrams and letters. Whilst the parties still were in the negotiating stage, the defendants withdrew the offer. When this matter was referred to the court, the court held that the parties were still in a state of negotiation and no agreement was formed. Therefore, the defendants were justified in withdrawing the offer.

If an acceptance is qualified by words such as 'subject to contract' or 'subject to formal contract being drawn up by our solicitors', the court would be inclined to hold in the absence of strong evidence that there is no contract made (Alsagoff, 2003). A conditional contract is not absolute and unqualified contract. The intention to create legal relation is also absent here (Alsagoff, 2003). In other words, it is incomplete contract and it can not be enforced by any party.

An example case on point of 'subject to formal contract' is Low Kar Yit \& or. V. Mohd Isa \& Anor (1963). In this case the defendant intended to sell a piece of land to the plaintiff. He said that the sale of the land should be subject to few conditions such as i) a formal contract to be drawn up and agreed upon by the parties; and ii) the sale contract should be approved by the High Court at Kuala Lumpur. The plaintiff duly exercised all the conditions but the defendant refused to sign the contract. Gill J. at the High Court in Malaysia held that no binding contract was made between the parties as the defendant did not sign the contract.

Where an acceptance is not absolute, the acceptance could only amount to a 'counter-offer' which ends the offer. For instance, if in his reply to an offer, the offeree introduces a new term or varies the terms of the offer, then that reply cannot amount to an acceptance. Instead, the reply is treated as a counter-offer, which the original offeror is free to accept or reject. A counter-offer amounts to a rejection of the original offer which cannot then be subsequently accepted (O'Sullivan and Hilliard, 2006).

In Hyde $v$ Wrench (1840), on 6 June $\mathrm{W}$ offered to sell his estate (farm) to $\mathrm{H}$ for $£ 1000$; H offered to buy for $£ 950$. On 27 June W rejected H's offer. On 29 June $\mathrm{H}$ offered to buy the farm for $£ 1000$. W refused to sell the farm at the reduced price and $\mathrm{H}$ sued for breach of contract. The dispute was referred to the court and Lord Langdale MR held that if W's offer to sell for $£ 1,000$ had been unconditionally accepted by $\mathrm{H}$, there would have been a binding contract; instead $\mathrm{H}$ made a counter-offer for the price of $£ 950$, and thereby he rejected the original offer previously made by $\mathrm{W}$. $\mathrm{H}$ afterwards could not revive the proposal of $\mathrm{W}$, by agreeing to accept the offer with the original price. Therefore, no obligatory contract was made on 29 June.

Where, however, the counter-offer is accepted unconditionally, a contract is made in terms of the counter-offer. This was decided in Butler Machine Tool Co. v Ex-Cell-O Corporation (1979). This case is related to the interesting concept of "battle of form" in contract formation. In the 'battle of form' in a contract, both the offeror and offeree provide their own standard terms for the sale contract and it becomes difficult to determine in what point of time the binding contract has already been made and on whose standard terms, the buyers or the seller? (O'Sullivan and Hilliard, 2006).

The fact of the case is that on 23 May 1969, the claimant sellers offered to deliver a machine tool for $£ 75,353$ on the terms set out in the question, which included a price escalation clause. The defendant buyers replied on 27 May, giving an order with differences from the sellers' quotation and stating that the order was on the buyers' terms and conditions, which did not include a price escalation clause. The order contained a tear off slip for the claimant to 
sign, which stated that the order was to be on the buyers' terms. On 5 June, the sellers returned the completed slip with a covering quotation of May 23'. When the machine came to be delivered, the claimant sought to rely on the price escalation clause. The Court of Appeal unanimously held that he could not, because a contract had been concluded on the buyers' terms.

The interesting thing about the case is the two different approaches taken, by Bridge and Lawton LJs on one hand, and Lord Denning MR on the other. The first two judges took an orthodox offer and acceptance approach. They looked at the last offer made by either of the parties and asked whether it was accepted by the other party. If it were there would be a contract on the terms set out in the last offer, if it was not, there would be no contract at all. This is known as the 'last shot' approach: he who makes the last offer wins (provided that it is accepted). On the facts, they held the buyers' reply on May 27 constituted a counter-offer and that despite the sellers' attempt to reassert their terms in the covering letter on June 5, they had in fact accepted the buyers' terms by returning the completed tear-off slip. So what appeared to be the last shot, the sellers' statement on 5 June, turned out to have misfired.

Lord Denning took a more radical route to the same conclusion. He rejected the traditional offer and acceptance analysis. Instead, he distinguished the issue of contract formation from the content of the contract. The first stage was to work out whether there was a contract. A contract would be formed if the parties were agreed on 'all material points': the fact that they might disagree on smaller points did not matter. In other words, only agreement on core issues is required to get the contract up and running. The next stage is to work out what the terms of the contract would be. Lord Denning stated that the terms would sometimes be those of the party who made the first offer, and yet in other cases, a reasonable compromise between the two. In order to decide which of these options should be adopted, 'the documents have to be considered as a whole'. Having done this, Lord Denning decided that the sellers' acknowledgement by the tear-off slip on 5 June was the decisive document, and this document made clear that the contract was on the buyers' terms.

A counter-offer should be distinguished from a mere request for information. In Stevenson $v$ McLean, on Saturday, the defendant offered to sell iron to the plaintiff at 40 shillings a ton, the offer to be open until Monday. On Monday at $10 \mathrm{am}$, the plaintiff sent a telegram asking if he could have credit terms. At 1:34 pm the plaintiff sent a telegram accepting the defendant's offer, but at 1:25 pm the defendant had sent a telegram: 'Sold iron to third party' arriving at 1:46 pm. The plaintiff sued the defendant for breach of contract and the defendant argued that the plaintiff's telegram was a counter-offer so the plaintiff's second telegram could not be an acceptance. It was held that the plaintiff's first telegram was not a counter-offer but only an enquiry. So, there was no contract by the first telegram. However, a binding contract was made by the plaintiff's second telegram.

\section{Acceptance by Acts or Omission}

Certainly, acceptance can be made in writing as well as orally as stated earlier. The question is: can acceptance be made by conducts (acts) and by omission. The answer is yes. Section 3 of the Contract Act 1950 (Malaysia) provides that the communications of acceptance is deemed to be made by any act or omission of the party. By the performance of an act the offeree accepts the offer and such performance of the act is akin to communicating the acceptance. So, in certain circumstances it is not necessary to communicate the acceptance formally. Performance of the conditions of the offer may constitute effective communication of the acceptance (Collins, 2003).

Section 8 of the Contracts Act 1950 (Malaysia) provides: "Performance of the conditions of a proposal...is an acceptance of the proposal". From this section we can understand that if a proposal includes a condition to be fulfilled by the offeree, the moment the offeree fulfills the condition he accepts the offer and in such cases communication of acceptance is not necessary (Simson, 1985). The performance of the condition of the offer automatically waives the requirement of communication of acceptance and this is in fact an exception to the general rule that an acceptance to be effective must be communicated to the offeror.

In Carlill v Carbolic Smoke Ball Co, the manufacturers of a medical preparation called the 'Carbolic Smoke Ball' placed an advertisement in a newspaper offering $£ 100$ to any person who contracted influenza after using the smoke balls as directed. As evidence of their good faith, the company deposited $£ 1,000$ in a bank account. Mrs. Carlill contracted influenza after using the smoke ball as directed and sued to recover the $£ 100$, which was refused by the defendant. It was held by the court that the advertisement was an offer to pay $£ 100$ to any person who would perform the conditions; performance of the conditions thus constituted acceptance of the offer, and notice of acceptance was not required (Simpson, 1985).

'Omission' can be a form of acceptance, but there is no case law to directly illustrate this. Nevertheless, the proposer (offeror) cannot, without the promisee's consent, put a condition in his proposal that the promisee's silence shall amount to acceptance. In fact, silence on the part of the offeror cannot impute acceptance and no binding contract. Hence, the offeror cannot unilaterally impose the condition that the offerree is bound by the agreement upon his 
failure to act or to accept the offer (Jalil et al, 2002). In Felthouse v Bindley, the plaintiff wanted to buy one of his nephew's horses. He wrote to his nephew who wanted to sell the horse to him, stating that "If I hear no more about him, I consider the horse is mine..." Subsequently, there was no notice from his nephew and the plaintiff considered the horse his own. The horse was not delivered to the uncle (the plaintiff), and later there was an auction at the nephew's property for the other livestock. The nephew told the auctioneer, Mr. Bindley, not to sell the horse at the auction. However, by accident Bindley sold the horse to another person. The plaintiff sued the auctioneer in tort for conversion but the action failed because the plaintiff could not show that actually he owned the horse.

The court ruled that the plaintiff did not have ownership of the horse as there was no acceptance of the contract. Acceptance must be communicated clearly and cannot be imposed due to silence of one of the parties. The uncle had no right to impose a sale through silence whereby the contract would only fail by repudiation. Though the nephew expressed an interest in completing the sale there was no communication of that intention.

\section{Manner of Acceptance}

Acceptance must be made in the manner prescribed by the offeror (Section 7(b) of the Contracts Act 1950 (Malaysia)). The offeror can stipulate that the acceptance must be made in a particular way. He may require it to be sent to a certain place, or to take a particular form, such as by letter or telex or e-mail. In order to complete a binding agreement, the offeree must normally comply with the prescribed method of acceptance. If the offeror stipulates a particular form of acceptance, and states that only the stipulated form will suffice, the offeree must comply with the offeror's requirement in order for there to be an effective acceptance. When the acceptor deviates from the prescribed manner, the offeror must not keep silent. If he does so and fails to insist upon the prescribed manner, he is considered as having accepted the acceptance in the modified manner (Section 7(b) of the Contracts Act 1950 Malaysia).

In common law, an acceptance communicated by any other mode which is no less advantageous will conclude a contract. For instance, an acceptance requested by return of post may be made by telegram or by verbal message. In other words, the offeror may have requested a particular method of acceptance for a specific purpose, for example to obtain a speedy reply. If the offeree uses some alternative method which equally achieves the offeror's purpose, there will be a valid acceptance. In Tinn v. Hoffman, the offer required acceptance by return of post, it was held by the court that there could be an acceptance by any means arriving not later than a letter sent by return, e.g. by telegram or by verbal message. It was held that "reply by return of post" included an equally speedy method.

The principle applied in Tinn v. Hoffman, was also applied in Manchester Diocesan Council for Education $v$. Commercial and General Investments Ltd and it was said that where the offeror has prescribed a particular method of acceptance, but not specifically insisting that only that mode of acceptance shall be binding, an acceptance communicated by any other mode which is no less advantageous to the offeror will conclude the contract.

\section{Communication of Acceptance}

As a general principle, acceptance must be communicated to the offeror to make a binding agreement (Section 3 of the Contracts Act 1950 (Malaysia)). Generally, when there is no communication of acceptance there is no contract. Acceptance speaks from the moment it is communicated (Abdullah \& Razali, 2008; Pheng, 2009; Furmston, 2001; Smith, 2006). Where the offeree merely intended to accept but did not communicate his intention to the offeror, there is no contract. That means a mere mental acceptance is not sufficient. Silence cannot constitute acceptance even if the offeror said, "By your silence and inaction you will be deemed to have accepted this offer" (Vohrah and Aun, 2009). This strict general rule applies because law wants that the acceptance as the gist of a contract must be express and certain (O'Sullivan and Hilliard, 2006). In Felthouse v. Bindley, (the facts have been stated above) there was no communication of acceptance by the defendant. The court held that the defendant did not communicate the acceptance to the plaintiff. So, there was no binding contract.

The general rule that silence will not constitute an acceptance can be justified on two grounds. Firstly, it protects the offeree from the consequences of an acceptance that he does not intend to accept. For example, you receive a large number of offers through your mailbox. Each of the offers states something along the lines 'if I do not hear from you by tomorrow morning, I will take you to have accepted my offer'. In the absence of the general rule, you have a duty to expressly reject all these offers in order to protect yourself from all these unwanted contracts.

This rationale (mentioned above) worked in Felthouse case (the facts mentioned above), where Wiles J commented that 'It is clear that uncle had no right to impose upon the nephew a sale of his horse for $£ 3015 \mathrm{~s}$. unless he chose to... repudiate the offer'. The Unsolicited Goods and Services Act 1971 (UK) allows people who received unsolicited goods to treat them as gifts in certain circumstances. Secondly, according to O'Sullivan and Hilliard 
(2006), silence is often equivocal. So if an offeree says and does nothing in response to the offer made to him, it is very difficult for the offeror (and court) to tell whether he intended to accept it.

The communication of an acceptance must be by the offeree or any person authorized by him. If the offeror is told of an acceptance by the offeree and the communication is made by someone without authority to make it, then in this situation, the communication is invalid. In the case Powell $v$ Lee, the plaintiff was an applicant for the post of headmaster of a school for which three candidates were interviewed. The management committee of the school at first decided to appoint the plaintiff, and authorized one of their numbers to inform other applicants that they had been unsuccessful. The management committee did not give any instruction to this member to inform the plaintiff that he has been selected for the position of headmaster for the school.

However, that member without authorization from the school management committee informed the plaintiff that he had been selected. Subsequently, the management committee changed their decision and decided not to employ the plaintiff. When they informed the plaintiff about this negative news, he challenged the decision in court and claimed that the management committee had breached the contract to appoint him since he had already received communication from one of the committee members of the school management committee that he had been selected in the interview. The court dismissed the claim of the plaintiff on the ground that the communication to him was unauthorized and the unauthorized communication of acceptance is inadequate to form a contract.

\subsection{The general rule of communication: The Instantaneous Method}

Acceptance, as a general rule, is effective, when it has been communicated. The communication of acceptance can be made by instantaneous means, such as face to face, or by telephone or telex. Where acceptance is communicated by instantaneous means of communication for example by telex, the communication of acceptance is complete when it is actually brought to the knowledge of the offeror (or proposer) (Lewis, 1980). In Entores v. Miles Far East, the plaintiffs in London made an offer by telex to the agents in Holland of the defendant corporation in New York. The offer was accepted by a communication received on the plaintiffs' telex machine in London. The plaintiffs sought leave to serve notice of a writ on the defendants in New York claiming damages for breach of the contract so made. The defendants argued that the contract was made in Holland.

The judge claimed that when a contract is made by post it is clear law throughout the common law countries that the acceptance is complete as soon as the letter is put into the post box, and that is the place where the contract is made. But there is no clear rule about contracts made by telephone or by telex. Communications by these means are virtually instantaneous and stand on a different footing. The Judge has given out three situations to analyse this argument.

(a) Face to face: Suppose, for instance, that I shout an offer to a man across a river or a courtyard but I do not hear his reply because it is drowned by an aircraft flying overhead. There is no contract at that moment. If he wishes to make a contract, he must wait till the aircraft is gone and then shout back his acceptance so that I can hear what he says.

(b) Telephone: Suppose, for instance, that I make an offer to a man by telephone and, in the middle of his reply, the line goes 'dead' so that I do not hear his words of acceptance. There is no contract at that moment. The other man may not know the precise moment when the line failed. But he will know that the telephone conversation was abruptly broken off because people usually say something to signify the end of the conversation. If he wishes to make a contract, he must therefore get through again so as to make sure that I heard. Suppose next, that the line does not go dead, but it is nevertheless so indistinct that I do not catch what he says and I ask him to repeat it. He then repeats it and I hear his acceptance. The contract is made, not on the first time when I do not hear, but only the second time when I do hear. If he does not repeat it, there is no contract. The contract is only complete when I have his answer accepting the offer.

(c) Telex: Suppose a clerk in a London office taps out on the teleprinter an offer which is immediately recorded on a teleprinter in a Manchester office, and a clerk at that end taps out an acceptance. If the line goes dead in the middle of the sentence of acceptance, the teleprinter motor will stop. There is then obviously no contract. The clerk at Manchester must get through again and send his complete sentence. But it may happen that the line does not go dead, yet the message does not get through to London. Thus the clerk at Manchester may tap out his message of acceptance and it will not be recorded in London because the link at the London end fails, or something of that kind. In that case, the Manchester clerk will not know of the failure but the London clerk will know of it and will immediately send back a message "not receiving." Then, when the fault is rectified, the Manchester clerk will repeat his message. Only then there is a contract. If he does not repeat it, there is no contract. 
The judge concluded in the above case that the rule about instantaneous communications between the parties is different from the rule about the post. The contract is only complete when the acceptance is received by the offeror: and the contract is made at the place where the acceptance is received. It was held that since the acceptance was received in England, the contract was made in England.

When acceptance is communicated by telex or fax the issue may arise of when the acceptance was received and when a binding contract is made. The answer to this issue is crucial as the telex or fax might be received during the weekend or holidays or out of office hours. This issue was discussed and elaborated in Mondial Shipping and Chartering Ltd $v$. Astarte Shipping Ltd. In this case, a notice was sent by telex just before midnight on a Friday and could not be read by the other party until Monday morning. The court held that the telex notice was communicated on Monday morning because from midnight on the Friday to Sunday, the office was closed and the acceptance did not come to the knowledge of the offeror.

If an acceptance was sent during office hours it would be received when it was sent by the telex or fax machine. The position will be different if the communication is sent outside office hours. Such a communication will become 'non-instantaneous'. A discussion has arisen of where a message is sent within the communicator's business hours but outside the recipient's business hours. For those in commerce who have to rely on such mechanisms should have preferred a certain indication of who bears the risk. In this example, the recipient's business hours will be taken into account, because his knowledge of the acceptance is crucial to make a valid contract (Lewis, 1980).

\subsection{Exceptions to the general rule: The postal rule}

Section 4(2)(a) of the Contracts Act 1950 provides that the communication of acceptance is complete as against the proposer when it is put in a course of transmission to him so as to be out of the power of the acceptor. With respect to the acceptor, Section 4(2)(b) of the Contracts Act (Malaysia) provides that the communication of acceptance is complete as against the acceptor (offeree) when it comes to the knowledge of the proposer (offeror).

Thus, acceptance by post as against the proposer takes effect as soon as it is posted(Note 1), even where the letter of acceptance is either delayed in the post or totally lost. A letter is posted when it is put into an official letter box or into the hands of an employee of the post office who is authorized to receive letters. In Adams v Lindsell,(Note 2) the defendants offered to sell wool to the plaintiffs, asking for a reply 'in course of post'. The defendants' letter was misdirected, so that the plaintiffs' reply was delayed beyond the normal course of post, and the defendants sold the wool to someone else. Nevertheless, the plaintiffs had sent a letter of acceptance on the same day they had received the offer, and claimed that there was an enforceable contract.

The court upheld that claim and held that a binding contract had been made. Since the decision in this case the rule has been that where acceptance is communicated by post the contract is formed as soon as the letter is posted, without need for it ever to reach the offeror. According to O'Sullivan and Hilliard (2006), if the offeree accepts by post, the general rule is that the offer will be accepted when the letter is posted, not when it reaches the offeror. This is known as the postal rule. Some critics suggest that the negative consequences of the postal rule sometimes make the postal rule unfair. They suggest that it should be the responsibility of the offeree to ensure that the letter reaches its destination (O'Sullivan and Hilliard, 2006, at 32).

The basis of the postal rule is that when no form of communication of acceptance is stipulated by the offeror, he is deemed to have taken the risk of non-delivery or misdelivery by post. In Ignatius $v$ Bell, the defendant gave an option to the plaintiff to purchase a piece of land on the condition that the option must be exercised on or before 20 August 1912 by a notice in writing. The plaintiff exercised the option by posting a letter on 16 August. The defendant only received the letter on 25 August. The plaintiff sued the defendant for specific performance. It was held that the parties had contemplated the use of the post as a means of communication and thus Section 4 of the Contracts Enactment (Malaysia) applies. According to Section 4 of this Enactment the acceptance is complete as against the proposer (the defendant), when it is put in a course of transmission to him so as to be out of the power of the acceptor. In other words, the acceptance was complete and a binding contract emerged when it was put into the post office on 16 August.

However, the postal rule does not apply (i) where the letter of acceptance has not been properly posted, as in $R e$ London and Northern Bank, where the letter of acceptance was handed to a postman who was authorized only to deliver mail and not to collect it. (ii) where the letter is not properly addressed. (iii) where the express terms of the offer exclude the postal rule, i.e., if the offer specifies that the acceptance must reach the offeror or the offeror says in his offer to the offeree that "Your answer by post is only to bind if it reaches me." Thus, the postal rule does not apply in case actual communication of acceptance was required by the offeror, that is the offeror must actually receive the acceptance letter to be bound by the contract. This is modification of the postal rule must be expressly mentioned by the offeror in his offer (Gardner, 1992). 
In Holwell Securities Ltd v Hughes, the defendant gave the plaintiff an option for the purchase of certain land, which was said to be exercisable by notice in writing to a given address within a certain period. An option is no more than an offer, and a letter accepting the offer in question was posted by the plaintiff, but failed to arrive. The Court of Appeal (UK) upheld the trial court's judgment in saying that there was no contract. The main finding in the both of the courts was that the mere words 'notice in writing to' were sufficient to override the postal rule. These words indicated that acceptance notice must reach the offeror. In this case, the court also stated that the postal rule would not be applied where it would produce a "manifest inconvenience or absurdity".

The negative aspect of the postal is that it protects the offeree at the expense of the offeror, as the offeror becomes bound by the contract without knowing the existence of the acceptance sent by the offeree, According to O'Sullivan and Hilliard (2006, at 78), "Where the postal rule applies, offerees are protected at the price of hardship to offerors. The offeror is put at risk to the extent that they are bound by a contract before they are aware of the fact of its existence."

While commenting on the decision of the court in Adams v. Lindsell (the facts written above) O'Sullivan and Hilliard (2006, at 78) observed that:

"In coming to their judgment the court in Adams appears to have decided that an offeror prepared to accept the risks inherent in using the postal system should also bear the risk of an acceptance getting lost or there being a delay. An offeror would be well-advised to exclude the postal rule by the terms of their offer and insist that they will only be bound on actual receipt of a posted acceptance."

The above advice of O'Sullivan and Hilliard is essential for businessmen when making contracts. As the contract is only made and becomes binding when the acceptance is communicated and to make sure that the acceptance is actually communicated to the offeor, he can expressly exclude the postal rule in the terms of his offer. Such a suggestion will mitigate the hardship of offerors who suffer from the negative consequences of the postal rule which has been applied in business transactions for almost the last two centuries.

At the present time different types of communication media have developed. There are so many communication media which available to businessmen to communicate acceptance of offer to sell something. The businessmen can combine two or more media to communicate the acceptance. For example, Mr. X accepted an offer to buy a car through the post office. He can make sure whether the acceptance letter has reached the offeror through land phone or mobile phone or by fax or by e-mail. Hence, it is recommended that common law countries may think to abolish the postal acceptance rule by amending the law that an acceptance by post will not be effective and complete until it reaches the offeror. Such a change of law at the present time is desirable as businessmen in almost all countries in the world have alternative media of communication of acceptance other than the post office, or they can use more than one media to communicate the acceptance (Jalil, 2010). Another point to be noted is that at the present time, the postal system has developed a lot. It is faster than before to send the letter through post office to the addressee and the postal authority has been more responsible and sincere in delivering the letters than it was one hundred years ago.

\subsection{Waiver of communication of acceptance}

There are some offers which by implication do not require actual communication of acceptance to the offeror. Offers of these kinds, in effect, invite the offeree to perform his acceptance rather than to communicate it. Such offers are recognizable from the language used and the nature of the transaction involved. The most common example is the offer to pay a reward, e.g. for the return of lost or stolen property. The return of the offeror's property constitutes the performance which amounts to acceptance of the offer. A contract made in this way is known as a unilateral contract. The celebrated example case on this point is Carlill v. Carbolic Smoke Ball Co. (1983). The facts and decision of this case have been written earlier.

In Errington $v$ Errington, a father allowed his son and daughter-in-law to live in a house which he had bought for $£ 750$. The father borrowed $£ 500$ on mortgage from a building society and told the couple that if they paid off the mortgage installments the house would be theirs. It was held by the Court of Appeal (UK) that the father's promise was a unilateral contract: a promise of the house in return for the couple's act of paying the installments. It could not be revoked by him once the couple performed the act by paying the installments, but it would cease to bind him if they left it incomplete and unperformed.

\subsection{Acceptance by e-mail/e-commerce}

There is no provision in the Contract Act 1950 Malaysia providing email as a mode of communication of acceptance. Where acceptance is sent by e-mail it may take the following path before it reaches the offeror:

(a) message sent from home PC to a local Internet Service Provider (ISP); 
(b) routed by the ISP's mail server via a larger ISP;

(c) routed by that ISP over a high bandwidth link to a traffic exchange;

(d) routed from there via another large ISP to a smaller ISP which hosts the offeror; and

(e) received by the offeror when he dials up his local ISP.

Considering the complication it creates, it is not clear which rule, the postal rule or the instantaneous rule applies in case of acceptance by e-mail. If the postal rule is applied, drawing a parallel between the ISP and the post box, difficulties arise since it begs the question: at which of the 4 ISPs is acceptance deemed communicated? Some people have doubt whether an e-mail can be considered as a form of instantaneous communication since it may take seconds or hours to reach its destination, depending on routing and other factors. Nevertheless, a company selling its products via the internet should state clearly on its web site the precise time and means by which acceptance will take place. This may be when the company acknowledges the receipt of the e-mail acceptance, or when the product is delivered, or, if it is in digital form, when it is downloaded. The company selling goods on the Internet should also state, as part of its terms, the choice of law governing the contract. This will avoid the court having to apply the "proper law of the contract" doctrine which considers the intention of the parties or localization of the contract.

ICT has developed a lot at the present time. Millions of businessmen and customers are using e-mail or other communication facilities on the Internet for example EDI, www interface etc. Message can be communicated on the internet very fast, for example, within few seconds if all the networks connected work properly. If there is a problem somewhere in the internet, the system will reply that e-mail delivery has failed for some reason. From the reply, businessmen and customers can understand that the acceptance could not be sent by e-mail or other ICT means. The response of an internet service about the success or failure of communication of acceptance is immediate. Therefore, we can say that communication through e-mail is instantaneous in nature and it is reliable and certain (Jalil, 2003; Murray, 2000).

As e-mail acceptance can be considered as instantaneous way of communication, we may propose that the instantaneous communication rule should be applied on the internet communication instead of applying postal rule (Jalil and Pointon, 2004). The postal rule has generated dissatisfaction among people and scholars for a long time considering its negative consequences. In fact, postal rule is not a general rule, it is an exception to the general rule. The general rule of communication of acceptance in contract law is instantaneous rule. Instantaneous rule of communication of acceptance is applied to face to face communication, mobile or telephone communication, telex or fax communication etc. E-mail communication also comes under instantaneous rule (Jalil and Pointon, 2004).

When an acceptance is communicated through the internet, it is important to determine precisely when and where the electronic contract actually is concluded (Dickie, 1998). In electronic contract the message is communicated through a digital message. Therefore, it has no geographical boundary or border. Offer and acceptance on the internet may emerge between two countries locating very far from each other. For example, the offeror may be in Malaysia and the offeree in the U.S.. The offeror offers to buy some audio-visual devices online by using e-mail from a U.S. company located in the U.S. The U.S. company accepts the offer by sending an e-mail message. There are two issues involved here: i) when does the binding contract emerge?; ii) where is the electronic contract concluded?

It is important to answer the above two questions to solve disputes which may arise out of online contracts. It is said that the electronic contract is concluded in the above example when or at the moment the computer system of the offeror in Malaysia receives the acceptance e-mail, no matter when he opens the computer and reads it. Regarding the place of occurrence of the contract, the buyer's place of business or residence will be taken into consideration, because it is the buyer who will ultimately receive the goods ordered online in his country, for example in Malaysia. So, the place where the electronic contract is concluded is Malaysia in the above example.

In face-to-face contracts, the parties meet together and sign the contract in some place either in the U.S. or in Malaysia or in Singapore. In that case the contract is concluded where the contract is signed for example in Singapore, although the sellers and buyers are from the U.S. and Malaysia. However, in internet contracts, the parties usually do not meet in any country to sign the contract. The contract is actually made by communicating electronic message through internet. Therefore, it is difficult to determine the exact place where the electronic contract was concluded.

Earlier in the discussion in this paper it was said that in e-mail communication the actual receipt rule should be applicable instead of the postal rule as the e-mail communication is instantaneous in nature. Similary, Mulcahy and Tillotson (2004) stated that: 
"Some authors have suggested that the usual receipt rule should apply (in e-mail communication) because the sender is ultimately in a position to know if the email has or has not been sent. It follows from the reasoning in The Brimnes case (1975) which viewed that the acceptance should become binding when the e-mail reaches the offeror's business premises or the place of their internet service provider during normal office hours."

Article 11 of the E-Commerce Directive 1999 (UK) provides some guidance in respect of non-business to business contracting. It provides that electronic orders and acknowledgments will be taken to be received when the addressee can access them in his computer system. This provision suggests that when the offeror can access the acceptance e-mail in this computer system that would constitute receipt of the acceptance. The Directive does not clearly explain when an electronic contract is concluded (Mulcahy and Tillotson, 2004).

\subsection{Acceptance by performance}

It is not always necessary that a formal contract should be prepared and signed by the parties to determine its validity. Sometimes, a contract can be presumed from the performance of instructions given by one of the parties and by conduct. When one party in a contract performs and follows all the instructions given by the other party and ultimately the contract is completed, no party in the contract can dispute the contract saying that no formal contract was drawn up by the parties and so, there was no valid contract and the defendant party will not be responsible for any defects in the contract performance. That situation arose in Percy Trentham Ltd v Archital Luxfer Ltd. (1993). In this case ' $\mathrm{A}$ ' wanted to build industrial units and subcontracted the work to make the units to ' $\mathrm{B}$ '. The work was done and paid for to ' $\mathrm{B}$ '. ' $\mathrm{A}$ ' then claimed damages from ' $\mathrm{B}$ ' because there were defects in the units. ' $\mathrm{B}$ ' argued that even though there had been letters, phone calls and meetings between the parties, there was no matching offer and acceptance and so no contract existed.

The Court of Appeal (UK) held that in this case, written and formal contract was irrelevant, a contract could be concluded even by conduct of the parties. Plainly, the parties intended to enter into a contract, the exchanges between them and the carrying out of instructions in those exchanges -- all supported A's argument that there was a course of dealing between the parties which amounted to a valid and working contract. Steyn LJ pointed out that: "The court takes an objective approach in deciding if a contract has been made. In the vast majority of cases a matching offer and acceptance will create a contract, but this is not necessary for a contract based on performance."

\section{Revocation of Acceptance}

When an offeree has accepted an offer and communicated the acceptance to the offeree, but the acceptance has still not been received by him (offeror), he may revoke it at any time before the acceptance is received by the offeror. If the offeror has already received the acceptance, the offeree cannot revoke it. In that case the revocation would not be effective. Revocation of acceptance must be communicated to the offeror. Revocation of acceptance can be communicated by an act or omission of the offeree (Section 3 of the Contracts Act 1950 Malaysia). Section 5(2) of the Contracts Act 1950 (Malaysia) provides:

"An acceptance may be revoked at any time before the communication of the acceptance is complete as against the acceptor but not afterwards".

For instance, B accepts A's proposal by a letter sent by post. B may revoke his acceptance at any time before or at the moment the letter communicating the acceptance reaches A, but not afterwards. The best way of revoking an acceptance is by way of an instantaneous method of communication for example by telephone or fax or e-mail, because it is very fast.

According to section 4(2) of the Contract Act 1950 (Malaysian) the communication of a revocation is complete:

(a) as against the person who makes it, when it is put into a course of transmission to the person to whom it is made, so as to be out of the power of the person who makes it;

(b) as against the person to whom it is made, when it comes to his knowledge.

The illustrations to Section 4(2) of the Contracts Act 1950 reads:

1) A proposes, by letter, to sell a house to $B$ at a certain price. The communication of the proposal is complete when B receives the letter. B accepts A's proposal by a letter sent by post. The Communication of the acceptance is complete - as against A, when the letter is posted; as against B, when the letter is received by A.

2) A revokes his proposal by telegram. The revocation of proposal is complete as against $A$ when the telegram is dispatched. It is complete as against B when B receives it. B revokes his acceptance by telegram. B's revocation of acceptance is complete as against $\mathrm{B}$ when the telegram is dispatched, and as against $\mathrm{A}$ when it reaches him.

So, the rule of revocation is very clear that the offeree must make sure that he has revoked his acceptance before it is received by the offeror or before it comes to the knowledge of the offeror and not afterwards. Any attempt to revoke an acceptance after it has already been received by the offeror would not be effective. 


\section{Different Aspects of Acceptance and Revocation in Diagrams}

Three diagrams have been shown in the Appendix on 'acceptance and revocation rule'. These diagrams show different aspects of acceptance and revocation while making a contract. Diagram 1 explains how negotiation takes place before an acceptance is made and a binding contract is created where both the parties agree it some point of time on the counter-offers and they become bound to fulfill the terms of the contract. During negotiation, the offeree may bargain about the price as explained and decided in Hide $v$. Wrench in our earlier discussion on the point.

In fact, during the negotiation stage, no acceptance is made and no binding contract emerges as the offeree does not accept the offer unequivocally and absolutely. For example, if the offeror states 'my terms of offer should be accepted unequivocally' but the offeree says "no, my terms of acceptance should be taken into consideration for making the contract and it will get priority over the offeror's terms," and this type of communication continues for several days, then a complicated situation arises where it is difficult to determine at what point of time a valid acceptance is made or it may happen that no contract has been at the end. This type of negotiation is known as 'battle of forms" for acceptance (Ball, 1989; Mulcahy and Tillotson, 2004; Adams, 1983). When a binding contract emerges at some point of time during negotiation, the parties are bound to fulfill the contract. If any party is in default to fulfill the terms of the contract, he will be liable for one or more remedies to the affected party including damages (Beale, 1975).

As stated earlier it is compulsory that the acceptance must be communicated to the offeror, if not the acceptance will not be taken into consideration. In other words, the acceptance will be ineffective and no binding contract will be formed. This is the general rule and it has exceptions in special circumstances as have been discussed above. Diagram 2 shows that the acceptance of an offer might be communicated to the offeror by using one or more of multiple media, such as i. by post; ii. face-to-face; iii. over the phone; iv. by fax or telex; v. by e-mail etc. But, the important issue is, in all these cases of communication when in fact an acceptance becomes complete and binding against the offeror. Earlier we have seen that if the acceptance is communicated through non-instantaneous mode of communication such as through post office, the acceptance is complete the moment the acceptance letter is posted in the letter box or given to an officer in the post office after it has been properly addressed and paying the correct postal fees. This is known as postal rule and it does not concern when the offeror receives the acceptance letter or whether he receives it at all.

On the other hand, in cases of instantaneous means of communication, such as face-to-face, by phone, by fax or telex, by e-mail etc. the receipt rule (which is also known as the instantaneous rule) will be applicable. The receipt rule requires that the communication of acceptance is complete when in fact it comes to the knowledge of the offeror. For, face-to-face communication and by telephone communication, the acceptance is complete when the offeror clearly understands the acceptance of the offeree and the acceptance is unqualified and absolute. In case of acceptance by fax or telex, the communication of acceptance is complete and a binding contract is made when the offeror receives the fax or telex. If the telex or fax is sent outside office hours or holidays, the receipt will be effective on the morning of the next day during office hours as has been stated earlier. For example, the fax communicating the acceptance is sent at 10:00 pm at night, the acceptance will be effective at around 9:00 am in the morning next day if office hours start at 9:00 am. In cases of fax or telex sent during holidays or of the weekend, the acceptance will be effective on the morning of the first day that the office opens after the weekend or the holiday. If the acceptance is communicated by e-mail, the acceptance is complete and binding against the offeror when the acceptance e-mail reaches the computer system of the offeror (Jalil, 2003). For e-mail communication, the business hours will be applicable, as in the case of the fax and telex communication rule.

Earlier we have discussed the circumstances under which the offeree can revoke the acceptance that he has sent to the offeror. Diagram 3 shows the time when the communication of revocation notice will be effective. The diagram shows that to revoke the acceptance, the offeree has to make sure that he revokes it before the offeror has received the acceptance letter or message or before the acceptance letter or message comes to his knowledge. If the revocation letter or message reaches the offeror after he has received the acceptance letter or message, then the revocation would not be effective. In that case, the contract will remain binding against the offeree and he is bound to fulfill the terms of the offer. If he fails to fulfill the terms of the offer, he will be liable for civil remedy such as damages, specific performance, injunction, rescission of the contract, quantum meruit etc. (Beale and Dugdale, 1975).

However, if the offeree is able to revoke the acceptance before it is communicated to the offeror, it is a successful revocation and in that case no binding contract is be made between the parties and the offeree would not be bound to fulfill the terms of the offer. So, to be successful in revoking an acceptance, the offeree must make sure that he has revoked the acceptance before it is received by the offeror and this is usually possible when the acceptance is communicated by letter sent by post. Let's say the offeree has sent the acceptance letter by post on 5 March and it will take 3 days to be received by the offeror (let's say on 8 March), the offeree can revoke the acceptance by phone 
on 6 or 7 March but not after the offeror has already received the acceptance letter. The problem of revocation arises when the acceptance is communicated by using instantaneous mode of communication, because in that case the offeree does not get enough time to revoke the acceptance as the offeror receives the acceptance message immediately or within few seconds or minutes.

\section{Conclusion}

From the above discussion we have seen that acceptance is one of the most important elements of a valid contract. Without acceptance no contract can be formed. Acceptance must be absolute and unqualified. There should not be any modification of the terms of an offer to have a valid acceptance as stated above. If there is bargaining involved in the acceptance, it is known as negotiation on price and quality of the goods and a contract might be made sometime at the end of the negotiation, but at the beginning of negotiation no contract is formed because introducing new terms in the offer in fact modifies the original offer and rejects it and it is known as making counter offer by the offeree.

This paper has discussed what is an acceptance, nature of an acceptance, communication of an acceptance, revocation of an acceptance, postal rule, instantaneous rule, e-mail rule, acceptance by performance, waiver of acceptance and so forth with the help of decided cases from the UK and Malaysia and referring to relevant sections of Contracts Act 1950 (Malaysia).

Electronic contract is proliferating online world wide. Hundred of billions of U.S. dollar value transactions are being made on the internet every year where contracts are made through the internet. What the rule of acceptance for contracts is on the internet has also been discussed in this chapter considering its new phenomenon and technological impact on business society. We have proposed that there is an opportunity to apply the instantaneous rule to electronic contracts as the internet is very fast in communication (like face to face or telephone communication). Internet communication sometimes may be delayed due to server disconnection (known as network disconnection) but it is a rare and temporary problem. On the other hand, the system automatically sends a notification of the problem and failure of communication to the sender's e-mail box. To solve the server disconnection problem in the internet, it is suggested that different modes of communication can be used for example fax or telephone along with e-mail.

\section{References}

Abdullah, N. Irwani and Razali, S. Salwani. (2008). Commercial Law in Malaysia, Kuala Lumpur: Prentice Hall.

Adams, J. (1983). "The battle of forms," JBL 297.

Alsagoff, Syed Ahmed. (2003). Principles of the Law of Contract in Malaysia, Kuala Lumpur: Lexis Nexis.

Ball. (1983). "Battle of forms," LQR 99:572.

Beale, H and Dugdate, T. (1975). "Contracts between businessmen: planning and the use of the contractual remedies," British Journal of Law and Society 45.

Collins, H. (2003). The Law of Contract, London: LexisNexis, Butterworths.

Coote. (1974). "Communication of Acceptance," NZULR 4:331.

Dickie, J. (1998). "When and where the electronic contract concluded," Northern Ireland Legal Quarterly, 332-334.

Furmston, M. (2001). Cheshire, Fifoot and Furmston's Law of Contract, London: Butterworths.

Gardner, S. (1992). "Trashing with Trollope: a deconstruction of the postal rules," Oxford Journal of Legal Studies, 197.

Hudson. (1966). “Revocation of postal Acceptance,” LQR 82:169.

Hudson. (1968). "Whether the offerre has to be aware of the offer to accept it," LQR 84:503.

Jalil, M. A.; Jawahitta, S.; et at. (2002). Basic Principles of Law, Malaysia: Prentice Hall, Pearson Malaysia Sdn. Bhd.

Jalil, Md Abdul. (2010). Commercial Law, (unpublished monograph).

Jalil, Md. Abdul and Pointon, Leo D. (2004). "Development in Electronic Contract Laws: Malaysian Perspective," Computer Law and Security Reports 20(2): 177-284.

Jalil, Md. Abdul, (2003), "Is the Contracts Act 1950 (Malaysia) Suitable on the Internet: A Critical Evaluation," Malaysian Journal of Law and Society, 20-30.

Lewis, C. (1980). "The formation and repudiation of contracts by international telex," LMCLQ 43.

Majid, Abdul and Arjunan, Krishnan. (2007). Business Law in Malaysia, Kuala Lumpur: Malayan Law Journal. 
Mulcahy, Linda and Tillotson, John. (2004). Contract Law in Perspective, London: Cavendish Publishing.

Murray, A. (2000). "Entering into contracts electronically: the real w.w.w." In Edwards, L. and Waelde, (eds), Law and the Internet: A Framework for Electronic Commerce, Oxford: Hart Publishing, 17-36.

O'Sullivan, Janet and Hilliard, Jonathan. (2006). The Law of Contract, New York: Oxford University Press.

Pheng, Lee Mei and Detta, Jvan Jeron. (2009). Business Law, New York: Oxford University Press.

Simpson, A. (1985). "Quackery and Contract Law: the case of the Carbolic Smoke Ball" Journal of Legal Studies 14:345.

Smith, Stephen A. (2006). Atiyah's Introduction to the Law of Contract, New York: Oxford University Press.

Vohrah, Beatrix and Aun, Wu Min. (2009). The Commercial Law of Malaysia, Malaysia: Longman, Pearson Malaysia Sdn. Bhd.

\section{Legislation}

Contracts Act 1950 (Malaysia)

Contracts law (UK)

Unsolicited Goods and Services Act 1971 (UK)

\section{Cases:}

Low Kar Yit \& Others v. Mohd. Isa \& Another [1963] MLJ 165.

Lau Brothers \& Co. v. Chin Pacific Navigation Co. Ltd. [1965] 1 MLJ 1.

Hyde v. Wrench [1840] 3 Beav 334.

Butler Machine Tool Co. v. Ex-Cell-O Corporation [1979].

Stevension v. Mc Lean [1880] 5 QBD 346.

Carlill v. Carbolic Smoke Ball Co. (1893) 1 QB 256.

Felthouse v. Bindley [1862] 11 CBNS 869; 7 LT 835.

Tinn v. Hoffman (1873) 29 LT 271.

Manchester Diocesan Council for Education v. Commercial and General Investments Ltd [1969] 3 All ER 1593.

Powell v. Lee (1908) 99 LT 284.

Entores v. Miles Far East [1955] 2 qb 327.

Mondial Shipping Chartering Ltd. V. Asterte Shipping Ltd. [1995] CLC 1011.

Adams v. Lindsell [1818] 1 B \& Ald 681.

Ignatius v. Bell [1913] 2 F MSLR 115.

Holwell Securities Ltd. v. Hughes [1914] 1 WLR 155.

Errington v. Errington [1952] 1 KB290.

Percy Trentham Ltd. v. Archital Luxfer Ltd. [1993] 1 LIoyd's Rep 25.

The Brimines [1975] QB 929.

\section{Notes}

Note 1. Adams v Lindsell, [1818] 1B \& Ald 681.

Note 2. [1818] 1 B \& Ald 681. 


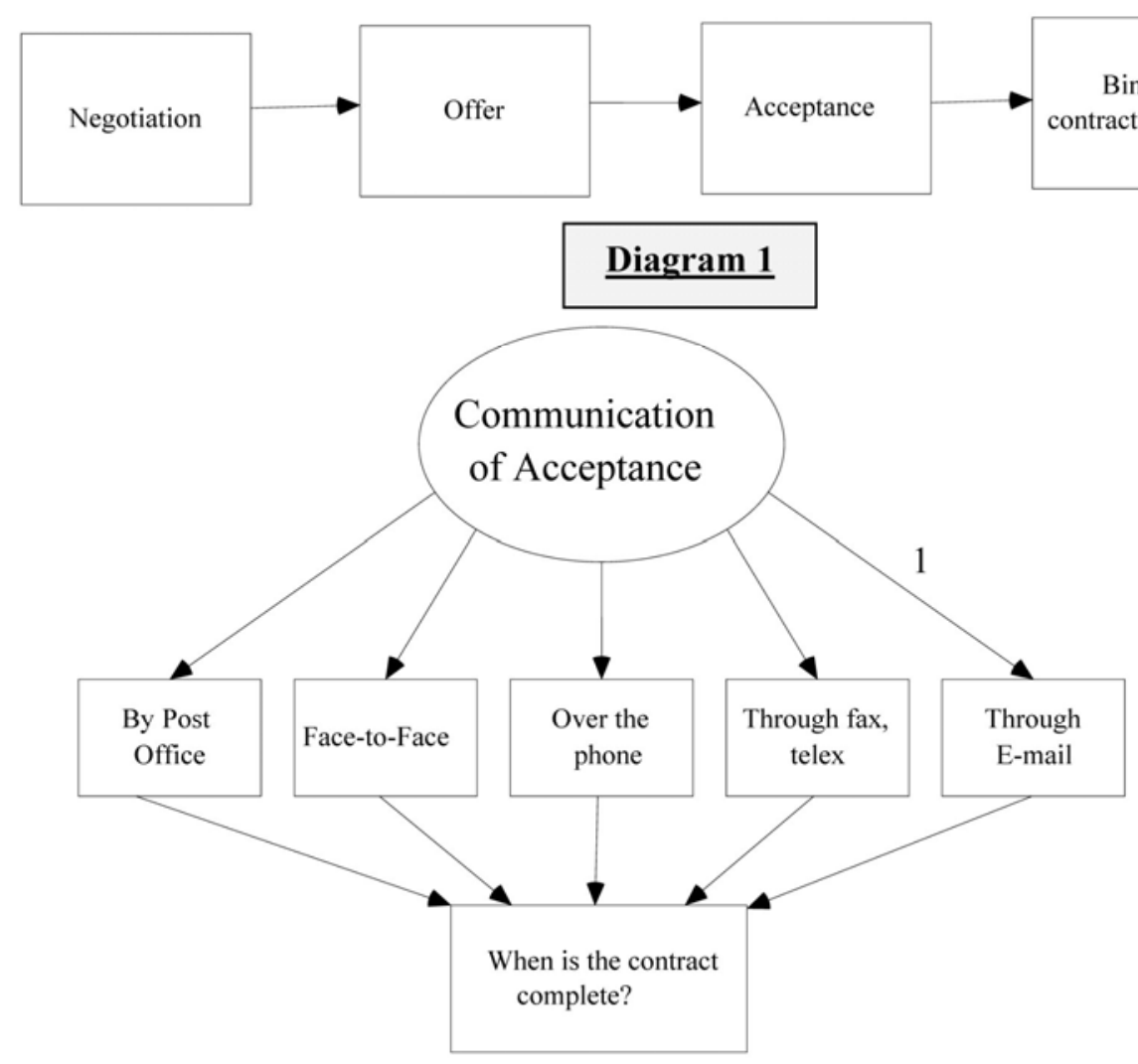

Diagram 2

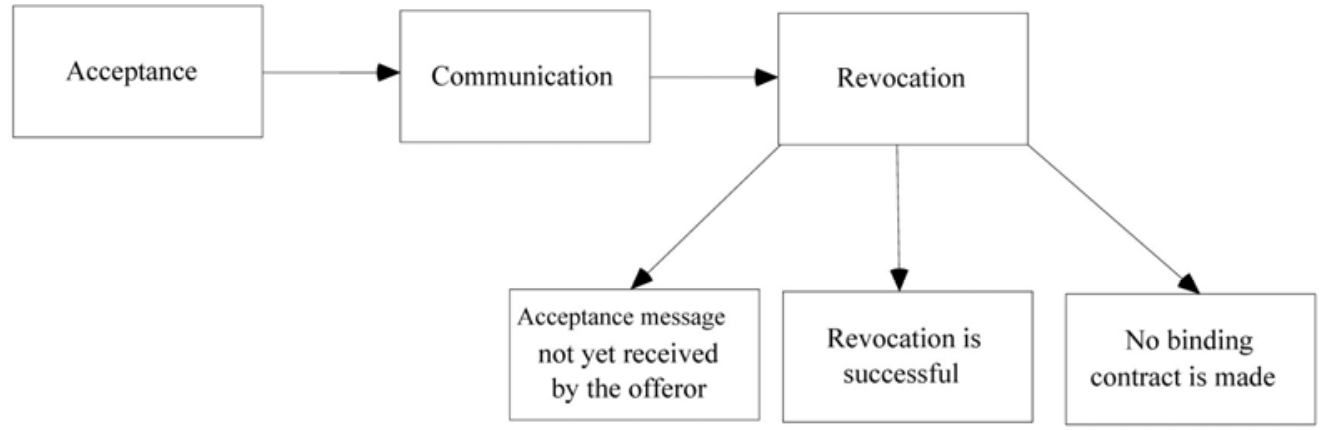

\section{Diagram 3}

